\section{Yield, Fruit Damage, Yield Loss, and Juice Quality Characteristics of Machine- and Hand-harvested 'Brown Snout' Specialty Cider Apples Stored at Ambient Conditions in Northwest Washington}

\author{
Travis Robert Alexander ${ }^{1}$, Jaqueline King, Edward Scheenstra, \\ and Carol A. Miles
}

\begin{abstract}
ADDITIONAL INDEX wORDs. labor, mechanical harvest, Malus $\times$ domestica, shake and catch, sweating
\end{abstract}

\begin{abstract}
SuMmary. In this 2-year study, 'Brown Snout' specialty cider apples (Malus $\times$ domestica) that had been hand harvested or machine harvested with an over-therow shake-and-catch small fruit harvester were ambient stored $\left(56^{\circ} \mathrm{F}\right.$ mean temperature) for 0,2 , and 4 weeks to evaluate yield, fruit damage, yield loss, and juice quality characteristics. The average yield (pounds per acre) of fruit picked and retained by the mechanical harvester was $74 \%$ that of the hand-harvest yield and $81 \%$ that of the hand-harvest yield when fruit that fell out of the harvester was included in the machine-harvest yield. Percent fruit bruised and cut were greater for machine harvest $(\mathbf{9 7 . 5 \%}$ and $\mathbf{2 5 . 5 \%}$, respectively) than for hand harvest $(47 \%$ and $\mathbf{0 . 5 \%}$, respectively), on average for 2014 and 2015 . Yield loss to rot was greater for machine harvest than for hand harvest, and increased for both methods over time; percent rot doubled from 2 to 4 weeks storage for machine harvest ( $22 \%$ to $41 \%$ ), and while negligible, tripled from 2 to 4 weeks storage for hand harvest $(0.7 \%$ to $2.1 \%)$. Juice quality characteristics did not differ due to harvest method, but did differ due to year and storage time. Soluble solids concentration [SSC (\%)] and specific gravity (SG) did not change due to storage in 2014 , but in 2015 , SSC and SG were greater on average for 2 and 4 weeks storage duration (15\% and 1.062 , respectively) than at harvest $(13.31 \%$ and 1.056 , respectively). Titratable acidity (grams per liter malic acid) decreased in 2014 from $2.98 \mathrm{~g} \cdot \mathrm{L}^{-1}$ at harvest to $2.70 \mathrm{~g} \cdot \mathrm{L}^{-1}$ on average for 2 and 4 weeks storage duration, but did not differ due to storage in 2015. Tannin [tannic acid equivalent (\%)] was unchanged in 2014 from harvest to 4 weeks storage, but increased in 2015 from $0.16 \%$ at harvest to $0.19 \%$ by 4 weeks storage. These results indicate that harvest efficiency could be improved with some engineering modifications of the over-the-row mechanical harvester and training modifications for the trees. A comparison of the aromatic and phenolic contents of mechanically harvested and hand-harvested 'Brown Snout' would be a valuable next step in evaluating shake-and-catch mechanical harvest technology for cider apple production.
\end{abstract}

$\mathrm{T}$ The cider (fermented apple juice, colloquially termed hard cider) industry is experiencing exponential growth in the United States. While accounting for just over $1 \%$ of the nation's alcoholic beverage market as of 2014 , cider production has increased 22-fold from 2007 to 2015 [Alcohol

Department of Horticulture, Washington State University, 16650 State Route 536, Mount Vernon, WA 98273

Funding support provided by the Washington State University Emerging Research Issues Grant, the Washington State Department of Agriculture Specialty Block Grant Project No. K1270, the Northwest Agricultural Research Foundation, and State project WN00427 Acc. no. 1000194 are gratefully acknowledged.

${ }^{1}$ Corresponding author. E-mail: travis.alexander@ wsu.edu.

doi: 10.21273/HORTTECH03474-16 and Tobacco Tax and Trade Bureau (TTB), 2016]. In 2007, $775,031 \mathrm{gal}$ of cider were produced in the United States, increasing to $17,101,697 \mathrm{gal}$ in 2015 (TTB, 2016). The volume of cider produced in Washington State grew 25fold from 2007 to 2015 (from 44,387 to $1,099,823 \mathrm{gal}$ ), and accounted for $6 \%$ of the total U.S. cider production in 2015 (TTB, 2016). The number of cideries in Washington increased more than 5 -fold in the last 9 years, from less than 10 cideries in 2007 to 56 reported cideries in 2015 (Northwest Cider Association, 2015; The Cyder Market, 2015). To fulfill the increasing demand for specialty cider apples, growers in the United States need innovative orchard practices (Milkovich, 2016). In the United Kingdom, which is the world's largest producer and consumer of cider, growers have minimized cost of production by exclusively harvesting cider fruit by machine (National Association of Cider Makers, 2010). Mechanized harvest systems for cider apple in the United Kingdom generally involve the use of tractormounted tree shakers that knock fruit to the ground and tractormounted air blowers and mechanical brushes that sweep fruit from the orchard floor, commonly referred to as shake-and-sweep harvest systems (Fitzgerald et al., 2013; Lea, 2008). These harvest systems have been developed for the traditional cider apple orchards in England and France, orchards with average densities of 283 trees/acre and located in regions with poor soil where dwarfing rootstock do not perform well (Durrant and Durrant, 2009). In Washington, modern cider apple orchards are dominated by dwarfing rootstocks ['Malling 9' (M.9), 'Malling 27' (M.27), 'Merton-Malling 106' (MM.106)] and have an average orchard density of $\approx 726$ trees/ acre in western Washington and 1452 trees/acre in central Washington (Galinato et al., 2014; Galinato and Miles, 2016, in press). Accordingly, the shake-and-sweep harvest systems are not well suited for Washington cider apple orchards as their shallow-rooted rootstocks, relatively small diameter trunks, and smaller row spacing prevent successful use

\begin{tabular}{llll}
\hline $\begin{array}{l}\text { Units } \\
\begin{array}{l}\text { To convert U.S. to SI, } \\
\text { multiply by }\end{array}\end{array}$ & U.S. unit & SI unit & $\begin{array}{l}\text { To convert SI to U.S., } \\
\text { multiply by }\end{array}$ \\
\hline 0.4047 & $\mathrm{acre}(\mathrm{s})$ & $\mathrm{ha}$ & $2.471 \mathrm{l}$ \\
29.5735 & $\mathrm{fl} \mathrm{oz}$ & $\mathrm{mL}$ & 0.0338 \\
0.3048 & $\mathrm{ft}$ & $\mathrm{m}$ & 3.2808 \\
3.7854 & $\mathrm{gal}$ & $\mathrm{L}$ & 0.2642 \\
0.4536 & $\mathrm{lb}$ & $\mathrm{kg}$ & 2.2046 \\
1.1209 & $\mathrm{lb} / \mathrm{acre}$ & $\mathrm{kg} \cdot h \mathrm{ha}^{-1}$ & 0.8922 \\
0.001 & $\mathrm{ppm}$ & $\mathrm{g} \cdot \mathrm{L}^{-1}$ & 1000 \\
$\left({ }^{\circ} \mathrm{F}-32\right) \div 1.8$ & ${ }^{\circ} \mathrm{F}$ & ${ }^{\circ} \mathrm{C}$ & $\left({ }^{\circ} \mathrm{C} \times 1.8\right)+32$ \\
& & & \\
\hline
\end{tabular}


of the machinery (Webster and Wertheim, 2003).

With Washington cider production having increased 25 -fold from 2007 to 2015 and labor demand having surpassed supply during the same time period, the ability of growers to harvest their orchards is increasingly threatened (Brady and Gallardo, 2014). The labor issue is exacerbated in the western half of the state, which lacks large commercialscale fruit production systems and the labor force and skillset that come with them (Thilmany, 2001). Recognizing the need for a mechanical harvest system that could function in Washington cider apple orchards and the potential food safety concerns that arise from using groundfalls, researchers at Washington State University (WSU) Mount Vernon Northwestern Washington Research and Extension Center (NWREC) carried out a proof-of-concept studyfrom 2011 to 2012 to evaluate the suitability of a shake-and-catch system (Miles and King, 2014). An over-the-row small fruit harvester traditionally used for harvesting blueberries (Vaccinium corymbosum) and processing raspberries ( $R$ ubus idaeus) was used to harvest 'Brown Snout' specialty cider apples. The study established that mechanization can decrease labor input and costs without negatively affecting juice quality characteristics for fruit stored up to 4 weeks under cold storage $\left(32^{\circ} \mathrm{F}\right)$. The study also found that with mechanization $100 \%$ of the fruit were bruised, 10\% sliced, and 4\% halved. Given that a significant number of cider apple growers in western Washington store their fruit at ambient temperature for up to 1 month, and that bruising accelerates fruit deterioration, it became apparent that the proof-of-concept study should be repeated with ambient storage (Kader, 1985; Lougheed and Franklin, 1974). In this 2-year study, 'Brown Snout' specialty cider apple was hand harvested or mechanically harvested and then ambient stored for 0,2 , and 4 weeks to assess the shake-and-catch harvest system for cider apple growers who desire or need to ambient store their fruit postharvest.

\section{Materials and Methods}

OrCHARD PLANTING. The 'Brown Snout' trees used for this study were grafted on two rootstocks, 'M.9' and 'M.27', and were established in 2002 at WSU NWREC in an orchard with soil type Skagit silt loam, a fine-silty, mixed, nonacid, mesic Typic Fluvaquent (U.S. Department of Agriculture, 2013). The trees were planted at 16-ft between-row and 4-ft in-row spacing, and were trained to a three-wire trellis system with the lowest wire $2 \mathrm{ft}$ above the soil surface to accommodate the mechanical harvester's catch plate. Harvest method (hand and machine) was randomized with four replicates per harvest method with an average of nine trees per plot; rootstock was not found to be significant by Miles and King (2014) and so in this study they were pooled together. The study was carried out in 2014 and 2015.

YIELD. Fruit was harvested when fully ripe, on 17 Oct. 2014 and 29 Sept. 2015. Fruit ripeness was measured with the $\mathrm{BC} /$ Ontario starch iodine index test; when greater than $90 \%$ of the fruit surface area of each sampling (three per row) was void of starch ( 8.5 on the Ontario chart), the fruit was considered fully ripe and the orchard was harvested (Blanpied and Silsby, 1992; Chu and Wilson, 2000; Lau, 1988). Both years, preharvest groundfalls were first removed from all plots immediately before harvest, then hand-harvest plots were picked first followed by the machine-harvest plots. Hand harvest was accomplished by four unskilled agricultural workers picking into grape boxes ( $40 \mathrm{lb} / \mathrm{box}$ ). Machine harvest was accomplished with an over-the-row small fruit harvester (model OR0012; Littau Harvester, Lynden, WA) driven by an experienced operator (Fig. 1). As the harvester passed over a tree, vertical spiked-drum shakers knocked fruit free onto a catch plate, the fruit rolled into cups that rotated through the top of the harvester, and two unskilled agricultural workers transferred the harvested fruit into grape boxes (40 lb/box).

Yield was measured as weight (pounds) of fruit harvested from each plot. For the hand-harvest treatment there was one yield recorded, which included the fruit picked from the trees and the fruit that fell to the ground during picking as currently practiced by cider apple growers. For the machine-harvest treatment, there were three yields recorded: 1) fruit
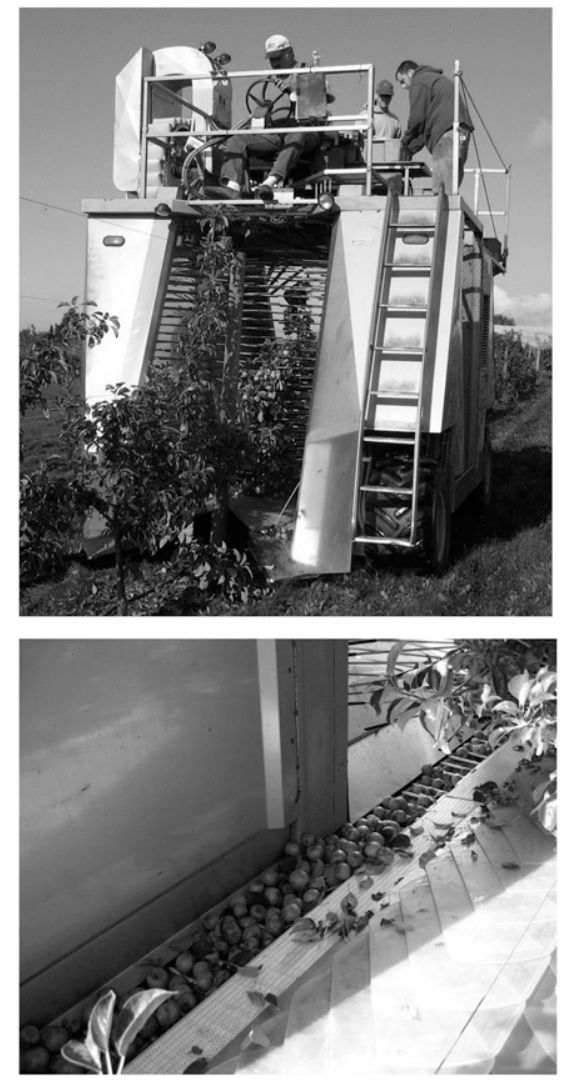

Fig. 1. Over-the-row small fruit machine harvester (model OR0012; Littau Harvester) harvesting 'Brown Snout' specialty cider apples (top); collection belt with harvested apples (bottom).

that was harvested by and collected from the machine; 2 ) fruit that was harvested by and collected from the machine and from the ground (fallen out of the machine post shaking); and 3 ) fruit that was harvested by and collected from the machine, from the ground, and from the trees (unharvested by the machine). Efficiency of mechanical harvest was compared with hand harvest for all three yields.

Fruit damage AND YIELD LOSS. In both years immediately after harvest, the filled grape boxes were placed in ambient storage conditions; in 2014 fruit was stored in a farm shed that was noninsulated but freeze protected (heated if temperature dropped below $45^{\circ} \mathrm{F}$ ), and in 2015 fruit were stored in an adjacent noninsulated and unheated barn. Both years' boxes of fruit were randomly assigned to three storage times: 0,2 , and 4 weeks. At the completion of each storage period, 100 fruit were randomly chosen from the respective boxes and the number of fruit that 
were bruised, cut, or rotted was counted per box, and percent damage and loss were calculated. The rotted fruit were subsequently discarded following common cider production practices.

JUICE QUALITY CHARACTERISTICS. Each year the 100 randomly selected fruit along with the remaining fruit in the box from which they were selected (all rotted fruit removed) were milled (MultiMax 30; Zambelli Enotech, Camisano Vicentino, Italy) and pressed (Carezza; Enotecnica Pillan, Camisano Vicentino, Italy), with equipment hose washed thoroughly between each sample. The respective juice samples were collected in 250-mL plastic bottles and frozen at $5{ }^{\circ} \mathrm{F}$ until the final storage treatment was completed and the respective fruit samples pressed. The juice samples from all treatments were thawed to room temperature $\left(74^{\circ} \mathrm{F}\right)$ and assayed. Juice analysis was carried out in the same laboratory both years, under controlled, and consistent experimental conditions. Juice was analyzed for five quality characteristics valued by cider makers: SSC (\%), SG, $\mathrm{pH}$, titratable acidity [TA (grams per liter malic acid)], and tannin [tannic acid equivalent (\%); Lowenthal, 1877]. SSC was measured with a digital refractometer (Palm Abbe model No. PA201; MISCO, Cleveland, $\mathrm{OH})$. SG was measured with a hydrometer [SG range 1.000-1.070, temperature calibration $60{ }^{\circ} \mathrm{F}$ (Bellwether; VeeGee Scientific, Kirkland, WA) ]. $\mathrm{pH}$ was measured with a digital $\mathrm{pH}$ meter (Orion 3 Star; Thermo Scientific, Pittsburgh, PA). TA was measured by titration with $0.2 \mathrm{M}$ sodium hydroxide $(\mathrm{NaOH})$ to a $\mathrm{pH}$ reading of 8.1 , measured in milliliters of titrant but reported as grams per liter malic acid. Tannin was measured using the Lowenthal permanganate titration method (Lowenthal, 1877). The specific protocol for each measurement was extracted from Miles and King (2014).

Statistical anAlysis. All statistical analyses were conducted using JMP software (version 11.0.0 for Windows; SAS Institute, Cary, NC). Levene's test was performed to evaluate the assumption of homogeneity of variances and the Shapiro-Wilk test performed to evaluate the assumption of normality. Parametric data were subjected to analysis of variance
(ANOVA). Least squares fit tests were performed to evaluate the main effects of year, harvest method, and storage time, and their two- and three-way interactions. Fisher's least significant difference test was used to compare treatment means at the $5 \%$ level. Nonparametric data (percent bruised fruit, percent cut fruit, and percent yield loss) were subjected to Welch's ANOVA. Wilcoxon signed-rank test was used for nonparametric comparison of treatment means at the $5 \%$ level.

\section{Results}

Storage CONDitions. From the first date of storage to the last date of storage in 2014 (17 Oct. to 14 Nov.), the temperature within the storage shed ranged from 42.8 to $77.0^{\circ} \mathrm{F}$ with an average of $55.4{ }^{\circ} \mathrm{F}$ (Hoboware H21-002; Onset Computer Corp., Bourne, MA). The temperature outside the storage shed ranged from 20.4 to $73.0^{\circ} \mathrm{F}$ with an average of $51.1^{\circ} \mathrm{F}$ (AgWeatherNet, 2016). In 2015, from the first date of storage to the last date of storage (29 Sept. to 27 Oct.), the temperature within the storage barn ranged from 45.2 to $67.5{ }^{\circ} \mathrm{F}$ with an average of $56.6^{\circ} \mathrm{F}$. The temperature outside the storage barn ranged from 38.6 to $70.3{ }^{\circ} \mathrm{F}$ with an average of $54.3^{\circ} \mathrm{F}$. The outside temperature was lower in 2014 than 2015 , but the daily average temperature inside the respective storage structures was similar both years (Fig. 2). In 2014, the temperature outside the storage shed dropped below freezing $2 \mathrm{~d}$ before completion
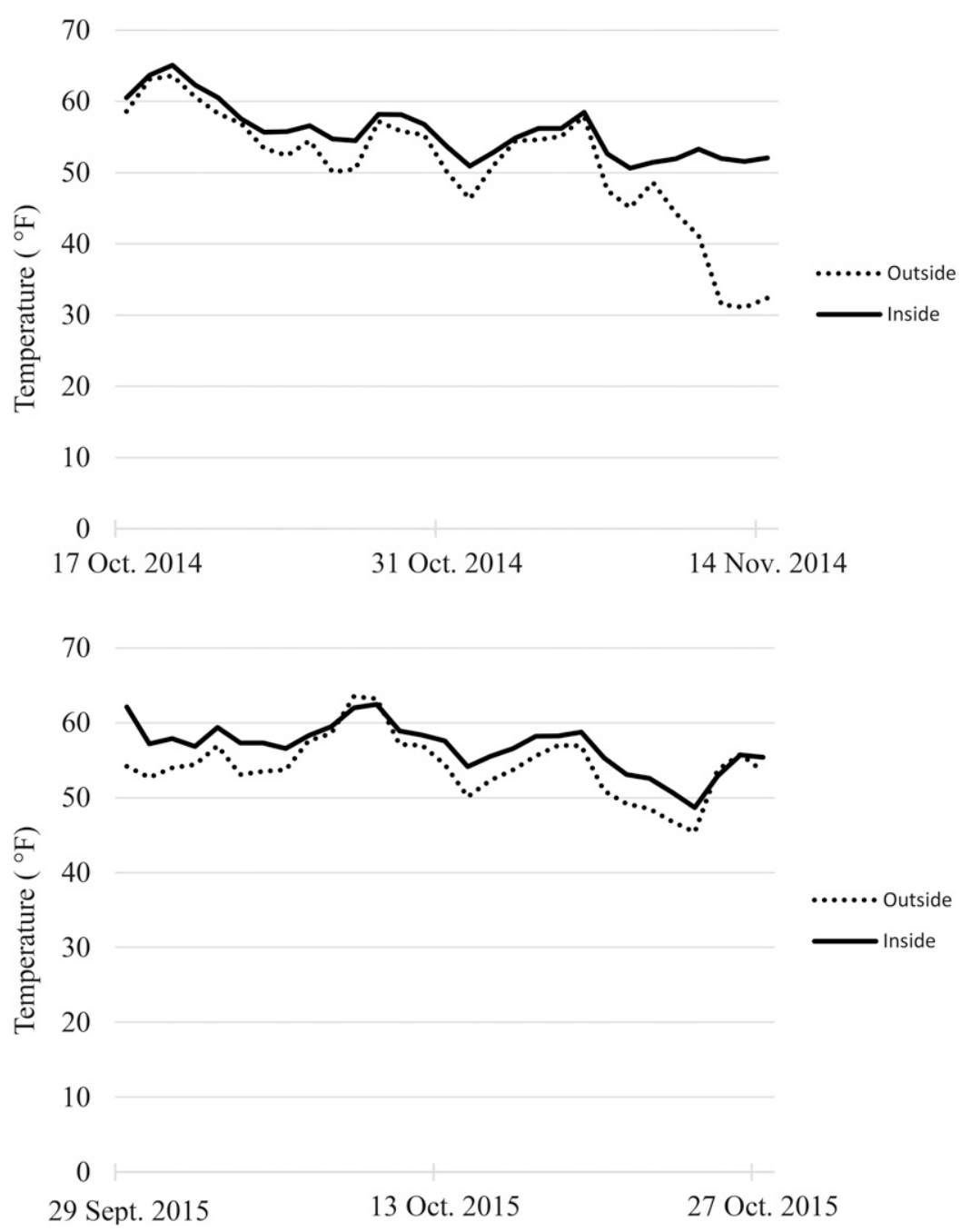

Fig. 2. Average daily temperature outside and inside the farm shed in 2014 and the barn in 2015 where 'Brown Snout' specialty cider apples were stored postharvest at Washington State University Mount Vernon Northwestern Washington Research and Extension Center. Fruit was harvested on 17 Oct. 2014 and 29 Sept. 2015 , and 2 weeks storage was until 31 Oct. 2014 and 13 Oct. 2015, whereas 4 weeks storage was until 14 Nov. 2014 and 27 Oct. $2015 ;\left({ }^{\circ} \mathrm{F}=32\right) / 1.8={ }^{\circ} \mathrm{C}$. 
of 4 weeks storage, but the storage shed's freeze protection heating system maintained an inside temperature similar to that inside the barn in 2015 .

YIELD. There were no significant differences between years $(P=0.74)$ or harvest methods $(P=0.36)$ for the yield (pounds per acre) of fruit picked (Table 1). Machine-harvest yield was $74 \%$ as efficient as hand harvest when only accounting for fruit picked and retained by the machine. When fruit that fell out of the machine were also included in yield, harvest efficiency was $81 \%$ as compared with hand harvest. And when fruit remaining on the tree was added to yield, harvest efficiency increased to $97 \%$. Labor and cost of harvesting were out of the scope of this study; however, these factors have been addressed by Galinato et al. (2016).

Fruit DaMage AND YIELD LOSS. There were significant differences between years $(P=0.04)$ and harvest methods for percent fruit bruised $(P<$ 0.0001 ), but there were no significant differences between storage times $(P=0.98$; Table 2$)$. The percentage of fruit that was bruised during hand harvest was lower in 2014 than in 2015 (15\% and 78\%, respectively). The low amount of bruising in 2014 was due to very cautious picking and transferring of fruit by the harvesting crew, whereas the percent of bruised fruit with hand harvest in 2015 was similar to levels found by Miles and King (2014) and likely represents levels to occur when unskilled labor is used to harvest apples. The percent of fruit bruised during machine harvest was similar both years ( $97.5 \%$ on average). Thus, the amount of fruit bruising is similar for machine harvest and hand harvest (1.2-fold increase) when unskilled harvest labor is used to harvest fruit, but a 6.5-fold increase in bruised fruit is likely for machine harvest when a skilled crew is available to handharvest fruit. There were no significant differences between years $(P=0.15)$ or storage times $(P=0.27)$ for percent fruit cut, but there was a significant difference between harvest methods $(P<0.0001)$. Percent fruit cut was greater for machine harvest than hand harvest (25.5\% and $0.5 \%$, respectively).

There was no difference between years for yield loss due to rot $(P=$ 0.38 ), but there were significant differences due to harvest method $(P=$ 0.02 ) and storage time $[P<0.0001$ (Table 3)]. Loss of fruit in storage due

Table 1. Mean total yield of hand-harvested 'Brown Snout' specialty cider apples in comparison with mean total yields of machine-harvested 'Brown Snout' (fruit that was harvested by and collected from the machine, fruit that was harvested by and collected from the machine and from the ground, and fruit that was harvested by and collected from the machine, from the ground, and from the trees), yields combined for 2014 and 2015.

\begin{tabular}{|c|c|c|c|}
\hline & Harvest method & Total yield (lb/acre $)^{\mathrm{z}}$ & Efficiency $(\%)^{y}$ \\
\hline Hand & & 11,760 & \\
\hline \multirow[t]{3}{*}{ Machine } & $\begin{array}{l}\text { Fruit harvested by and } \\
\text { collected from the machine }\end{array}$ & 8,699 & 74 \\
\hline & $\begin{array}{l}\text { Above plus fruit that fell } \\
\text { out of the machine }\end{array}$ & 9,530 & 81 \\
\hline & $\begin{array}{l}\text { Above plus fruit that } \\
\text { was left on the trees }\end{array}$ & 11,392 & 97 \\
\hline$P$ value $^{\mathrm{x}}$ & & 0.36 & \\
\hline
\end{tabular}

${ }^{\mathrm{z}} \mathrm{l} \mathrm{lb} / \mathrm{acre}=1.1209 \mathrm{~kg} \cdot \mathrm{ha}^{-1}$

y Calculated as the total yield for machine harvest divided by hand harvest.

${ }^{x}$ Significance of treatment effects were analyzed with analysis of variance using JMP software (version 11.0.1 for Windows; SAS Institute).

Table 2. Mean bruised and cut fruit for hand harvest and machine harvest of 'Brown Snout' specialty cider apples at Washington State University Mount Vernon Northwestern Washington Research and Extension Center in 2014 and 2015. Data were pooled for storage time, as this was insignificant $(P=0.98)$.

\begin{tabular}{lccc}
\hline & \multicolumn{2}{c}{ Bruised fruit $(\%)^{\mathrm{z}}$} & \\
\cline { 2 - 3 } Harvest method & $\mathbf{2 0 1 4}$ & $\mathbf{2 0 1 5}$ & Cut fruit (\%) $)^{\mathbf{z}, \mathbf{y}}$ \\
\hline Hand & 15 & 78 & 0.5 \\
Machine & 98 & 97 & 25.5 \\
v $_{\text {value }}^{\mathrm{x}}$ & $<0.0001$ & $<0.0001$ & $<0.0001$
\end{tabular}

${ }^{\mathrm{z}}$ Mean number of fruit that were observed to be bruised or cut out of 100 fruit randomly chosen for damage assessment at the completion of each storage time.

y Data pooled for 2014 and 2015 as no significant difference due to year $(P=0.15)$.

'Significance of treatment effects were analyzed with Welch's analysis of variance using JMP software (version 11.0.1 for Windows; SAS Institute)

to rot was greater for machine harvest than hand harvest at both 2 weeks (22\% and $0.7 \%$, respectively) and 4 weeks ( $41 \%$ and $2.1 \%$, respectively). Although rot doubled for machine harvest and tripled for hand harvest from 2 to 4 weeks, the amount of rot of hand-harvested fruit was negligible in storage. When these losses were extrapolated to loss of fruit per acre based on yields attained in this study, hand-harvested fruit loss was $82 \mathrm{lb} /$ acre after 2 weeks storage and $247 \mathrm{lb} /$ acre after 4 weeks storage, whereas for machine-harvest fruit loss was up to $2097 \mathrm{lb} /$ acre after 2 weeks storage and $3907 \mathrm{lb} /$ acre after 4 weeks of storage.

JUICE QUALITY CHARACTERISTICS. There was no significant difference due to harvest method $(P>0.05)$ for any of the juice quality characteristics measured; however, there were significant differences $(P<0.05)$ due to year and storage time for most of the juice quality characteristics measured in this study (Table 4). SSC and SG did not change due to storage in 2014 , but in 2015 SSC and SG were greater at 2 and 4 weeks storage (15\% and 1.062 on average, respectively) than at harvest $[13.31 \%$ and 1.056 , respectively $(P=0.0002)]$. $\mathrm{pH}$ increased in 2014 from 4.04 at harvest to 4.11 after storage $(P=0.01)$, but there was no difference in $\mathrm{pH}$ in 2015. TA decreased in 2014 from $2.98 \mathrm{~g} \cdot \mathrm{L}^{-1}$ at harvest to $2.70 \mathrm{~g} \cdot \mathrm{L}^{-1}$ after storage $(P=0.03)$, but did not differ due to storage in 2015. Tannin remain unchanged in 2014 from harvest to 4 weeks storage, but increased in 2015 from $0.16 \%$ at harvest to $0.19 \%$ by 4 weeks storage $(P=0.03)$.

\section{Discussion}

The over-the-row shake-andcatch small fruit harvester achieved $81 \%$ of the yield of hand harvest when all mechanically picked fruit were taken into account; whereas, a further $16 \%$ of fruit were left on the trees. Of this $81 \%, 7 \%$ of the fruit fell to the ground during mechanical harvest, which could be easily prevented by adding netting to the front and back of the machine. Ground falls can be 
used in cider production, but these fruit must be strictly separated, and free of any decomposition. Fermentation is generally accepted as a microbial kill step, having been shown to reduce patulin levels significantly below the FDA guideline limit of $50 \mu \mathrm{g} \cdot \mathrm{L}^{-1}$ (Moss and Long, 2002; Stinson et al., 1978). The maximum efficiency achieved in this study represents a $9 \%$ increase from the maximum efficiency achieved by Miles and King (2014). Increased brush rotation speed and familiarity with the machinery could explain the increased operational efficiency. However, in both studies a relatively significant amount of fruit remained on the tree following mechanical harvest, and further adjustments of the mechanical harvester are needed to optimize picking efficiency. Further, the spray application of hormone such as ethephon to provide a more uniform maturity at harvest could help reduce the number of fruit left on the trees (Unrath, 1972). It is important to note that the orchard density and tree height used in this study were lower than for typical orchard systems in Washington or elsewhere. Furthermore, tree health in the study orchard has been in decline due to apple anthracnose canker (Neofabraea malicorticis). Thus yield of 'Brown Snout' in this study is 1.4 to 2.8 times lower than for orchards where trees are planted with optimal spacing and trees are maintained at a maximum height based on the rootstock capacity (Galinato et al., 2016). Over-the-row shake-and-catch harvesters appear to be a viable option for cider apples, and yield (pounds per acre) could be increased if orchard density was greater (726 trees/acre as commonly used for cider apple orchards in western Washington or 1452 trees/ acre as commonly planted in central Washington), trees were maintained at a height of 10 to $12 \mathrm{ft}$, and a larger overthe-row harvester designed for trees such as olive (Olea europaea) were used.

Table 3. Mean loss of yield due to rotting for hand-harvested and machineharvested 'Brown Snout' after 0, 2, and 4 weeks ambient storage, averaged for 2014 and 2015.

\begin{tabular}{llcrcr}
\hline & \multicolumn{2}{c}{ Loss $(\%)^{\mathrm{z}}$} & & \multicolumn{2}{c}{ Rotted fruit $(\mathbf{l b} / \text { acre })^{\mathrm{y}}$} \\
\cline { 2 - 3 } \cline { 5 - 6 } & Hand & Machine & & Hand & Machine \\
\hline 0 weeks & $0.0 \mathrm{~b}^{\mathrm{x}}$ & $0 \mathrm{c}$ & & 0 & 0 \\
2 weeks & $0.7 \mathrm{ab}$ & $22 \mathrm{~b}$ & & 82 & 2,097 \\
4 weeks & $2.1 \mathrm{a}$ & $41 \mathrm{a}$ & & 247 & 3,907 \\
${\text { P } \text { value }^{\mathrm{w}}}$ & 0.04 & $<0.0001$ & & & \\
\hline
\end{tabular}

${ }^{2}$ Mean number of fruit that were observed to be rotted and marked for disposal out of 100 fruit randomly chosen for damage assessment at the completion of each storage time.

"Weight of rotted fruit was calculated based on percent loss for hand harvest $(11,760 \mathrm{lb} / \mathrm{acre})$ and for machine harvest $(9530 \mathrm{lb} /$ acre $) ; 1 \mathrm{lb} /$ acre $=1.1209 \mathrm{~kg} \cdot \mathrm{ha}^{-1}$.

${ }^{x}$ Means within a columns followed by a different letter are significantly different at $P \leq 0.05$, as determined by Wilcoxon signed-rank test.

"Significance of treatment effects were analyzed with Welch's analysis of variance using JMP software (version 11.0.1 for Windows; SAS Institute).
In both years of the study, machine harvest resulted in significantly greater bruising (almost $100 \%$ ) and cutting of the fruit as compared with hand harvest. Fruit were cut by the sharp edges of the machine as the fruit were carried by the belts around the $90^{\circ}$ corners on their way to the top of the machine where they were offloaded into crates. The belts of the harvester are fitted with cups suitable for small fruit (raspberries), and the medium-sized fruit of 'Brown Snout' protruded out of the cup and in some cases were jammed in the corners of the machine. In this study, fruit that was cut or dramatically bruised deteriorated in storage and accounted for the significant amount of rotten fruit by 4 weeks of ambient storage ( $41 \%$ of fruit rotted). Thus, eliminating causes of fruit cutting and dramatic bruising by the harvester would have a significant impact on yield of stored fruit. If a cider apple orchard in full production in western Washington were to lose $22 \%$ of its yield after 2 weeks of ambient storage, this would be equivalent to about losing $8835 \mathrm{lb} /$ acre of apples (assuming a yield of 40,158 lb/ acre) or $\$ 3092 /$ acre [assuming a price of $\$ 0.35 / \mathrm{lb}$ (Galinato et al., 2016)]. Consequently, it is recommended that adoptive growers modify the harvester as suggested, and cold-store fruit as established by Miles and King (2014) or press fruit within $24 \mathrm{~h}$ of harvest as is done in Europe where mechanical harvest is used for cider apples.

Postharvest storage of cider fruit at ambient conditions before pressing is a common practice among craft cider makers, referred to as

Table 4. Juice quality characteristics, SSC, SG, pH, TA, and tannin of 'Brown Snout' specialty cider apples stored at 0 , 2 , and 4 weeks ambient storage in 2014 and 2015.

\begin{tabular}{lllllcc}
\hline Yr & Time of analysis & SSC (\%) & SG (ratio) & pH & TA $\left(\mathbf{g} \cdot \mathbf{L}^{-1}\right.$ malic acid) & Tannin (\% tannic acid equivalent) \\
\hline 2014 & At harvest & 14.13 & 1.060 & $4.04 \mathrm{~b}^{\mathrm{x}}$ & $2.98 \mathrm{a}$ & $0.12 \mathrm{~b}$ \\
& 2 weeks & 14.96 & 1.063 & $4.10 \mathrm{a}$ & $2.83 \mathrm{~b}$ & $0.14 \mathrm{a}$ \\
& 4 weeks & 14.71 & 1.060 & $4.12 \mathrm{a}$ & $2.56 \mathrm{~b}$ & $0.12 \mathrm{~b}$ \\
Pvalue $^{\mathrm{w}}$ & Storage time & 0.14 & 0.27 & 0.01 & 0.03 & 0.03 \\
& Harvest method & 0.96 & 0.79 & 0.06 & 0.40 & 0.40 \\
& At harvest & $13.31 \mathrm{~b}$ & $1.056 \mathrm{~b}$ & 3.96 & 3.11 & $0.16 \mathrm{~b}$ \\
& 2weeks & $15.06 \mathrm{a}$ & $1.062 \mathrm{a}$ & 3.95 & 3.26 & $0.19 \mathrm{a}$ \\
& 4 weeks & $14.93 \mathrm{a}$ & $1.062 \mathrm{a}$ & 3.97 & 3.06 & $0.19 \mathrm{a}$ \\
Pvalue $^{\mathrm{x}}$ & Storage time & 0.0002 & 0.001 & 0.41 & 0.47 & 0.03 \\
& Harvest method & 0.36 & 0.20 & 0.09 & 0.23 & 0.10 \\
\hline
\end{tabular}

SSC = soluble solids concentration; TA = titratable acidity

${ }^{\mathrm{z}} \mathrm{SG}$ is the ratio of the density of the juice to the density of pure water.

${ }^{\mathrm{y}} 1 \mathrm{~g} \cdot \mathrm{L}^{-1}=1000 \mathrm{ppm}$.

${ }^{x}$ Means within a column followed by a different letter are significantly different $(P \leq 0.05)$, as determined by Fisher's least significant difference test.

wignificance of treatment effects were analyzed with analysis of variance using JMP software (version 11.0.1 for Windows; SAS Institute). 
"sweating," and done to concentrate soluble sugar levels (Lea, 2008; Tandem Ciders, 2015). In 1 out of 2 years of this study, soluble sugar levels (as measured by SSC and SG) did not increase with storage. In the year where soluble sugar levels did increase, they increased after 2 weeks of ambient storage, but levels did not increase between 2 and 4 weeks of ambient storage. Thus, for 'Brown Snout' harvested at full maturity, storing fruit after harvest does not appear to be necessary as soluble sugar levels are at their maximum levels at harvest. Cider apple growers should consider measuring fruit maturity using the starch iodine index test and only harvest fruit when it reaches full maturity to maximize soluble sugar levels in the harvested fruit and minimize the need for storing fruit. The juice quality characteristics $\mathrm{pH}, \mathrm{TA}$, and tannin also did not differ due to harvest method or storage time under ambient conditions, indicating that mechanical harvest is well suited to cider apple production, and it is not necessary to store cider apples postharvest to improve juice quality characteristics.

To have a better understanding of the impact of mechanical harvest on cider apple juice quality, and the finished cider product, more work is needed to determine if damaged fruit, which are more prone to rot as exhibited in this study, produce offflavors in pressed juice as demonstrated by Lea (2008) and Trowbridge (1917). Future studies should assess the impact of physical damage on fruit phenolic and aromatic contents at harvest and over storage time. Phenolics are crucial secondary metabolites in cider apple fruit; they influence the aroma, color, taste (astringency and bitterness), and fluid clarity of the final alcoholic product (Lea, 1990). Phenolics can also influence how long a cider is left to mature, how it is clarified, and how it is perceived upon consumption. Thus, future studies should investigate phenolic and aromatic contents of juice and the finished cider product.

\section{Literature cited}

AgWeatherNet. 2016. Washington State University Mount Vernon station historical data. 26 May 2016. <http://weather. wsu.edu/?p=93150>.

Alcohol and Tobacco Tax and Trade Bureau. 2016. Cider statistics CY 2007-2015.
Alcohol Tobacco Tax Trade Bureau, Washington, DC.

Blanpied, G.D. and K.J. Silsby. 1992. Predicting harvest date windows for apples. Cornell Coop. Ext. Publ. Info. Bul. 221.

Brady, M.P. and R.K. Gallardo. 2014. Labor prospects for the Washington tree fruit industry. Washington State Hort. Assn. Annu. Mtg. 2014. p. 1-36.

Chu, C.L.G. and K.R. Wilson. 2000. Evaluating maturity of 'McIntosh' and 'Red Delicious' apples. Ontario Ministry Agr. Food Rural Affairs Publ. Order No. 00-025. 3 May 2016. <http://www. omafra.gov.on.ca/english/crops/facts/ 00-025.htm>.

Durrant, R. and E. Durrant. 2009. Best practice, site preparation and design, p. 4-5. In: The state of apple orcharding. 3 May 2016. <http://www. archiveofciderpomology.co.uk/ archivereports/stateoforcharding2009. pdf>.

Fitzgerald, J., A. Berrie, C. Jay, L. Copas, J. Worle, G. Arnold, and J. Thatcher. 2013. Developing cider orchards for modern cider production. Asp. Appl. Biol. 111:1-3.

Galinato, S.P., R.K. Gallardo, and C.A. Miles. 2014. Cost estimation of establishing a cider apple orchard in western Washington. Washington State Univ. Ext. Publ. FS141E.

Galinato, S.P. and C. Miles. 2016. 2015 Cost estimates of establishing and producing specialty cider apples in central Washington. Washington State Univ. Ext. Publ. (In press.).

Galinato, S.P., C.A. Miles, and T.R. Alexander. 2016. Feasibility of different harvest methods for cider apples: Case study for western Washington. Washington State Univ. Ext. Publ. TB32E.

Kader, A.A. 1985. Quality factors: Definition and evaluation for fresh horticultural crops, p. 118-121. In: A.A. Kader (ed.). Postharvest technology of horticultural crops. Agr. Natural Resources Publ., Univ. California, Berkeley, CA.

Lau, O.L. 1988. Harvest indices, dessert quality, and storability of 'Jonagold' apples in air and controlled atmosphere storage. J. Amer. Soc. Hort. Sci. 113:564-569.

Lea, A. 1990. Bitterness and astringency: The procyanidins of fermented apple ciders, p. 123-143. In: R.L. Rousseff (ed.). Bitterness in foods and beverages, Elsevier, Oxford, United Kingdom.

Lea, A. 2008. Craft cider making. Good Life Press, Preston, United Kingdom.
Lougheed, E.C. and E.W. Franklin. 1974. Ethylene production increased by bruising of apples. HortScience 9:192-193.

Lowenthal, J. 1877. Uber die bestimmung des gerbstoffs. Z. Anal. Chem. $16: 33-48$.

Miles, C.A. and J. King. 2014. Yield, labor, and fruit and juice quality characteristics of machine and hand-harvested 'Brown Snout' specialty cider apple. HortTechnology 24:519-526.

Milkovich, M. 2016. Growing demand for hard cider fuels growing demand for apples. 23 June 2016. <http:// fruitgrowersnews.com/news/9541/>.

Moss, M.O. and M.T. Long. 2002. Fate of patulin in the presence of the yeast Saccharomyces cerevisiae. Food Addit. Contam. 19:387-399.

National Association of Cider Makers. 2010. NACM statistics. 3 May 2016. <http://cideruk.com/files/publications/ NACM_Charts_for_Website_-_6_21Dec2010.pdfs.

Northwest Cider Association. 2015. Northwest cider association members. 3 May 2016. <http://www.nwcider.com/ member-cideries $/>$.

Stinson, E.E., S.F. Osman, C.N. Huhtanen, and D.D. Bills. 1978. Disappearance of patulin during alcoholic fermentation of apple juice. Appl. Environ. Microbiol. 36:620-622.

Tandem Ciders. 2015. The cider making process. 10 May 2016. <http://www. tandemciders.com/making-hard-cider. html>.

The Cyder Market. 2015. Domestic cider: Washington cidermakers. 9 Mar. 2016. <https://cydermarket.com/Washington. html>.

Thilmany, D.D. 2001. Farm labor trends and management in Washington State. J. Agribusiness 19:1-15.

Trowbridge, J.M. 1917. The cider makers' hand book-A complete guide for making and keeping pure cider. Orange Judd, New York, NY.

Unrath, C.R. 1972. Effects of preharvest application of ethephon on maturity and quality of several apple cultivars. HortScience 7:77-79.

U.S. Department of Agriculture. 2013. Web soil survey. 3 May 2016. <http:// websoilsurvey.sc.egov.usda.gov.html>.

Webster, A.D. and S.J. Wertheim. 2003. Apple rootstocks, p. 111-119. In: D.C. Ferree and I.J. Warrington (eds.). Apples: Botany, production, and uses. CABI, Cambridge, MA. 